\title{
KUPU-KUPU DI KAWASAN KONSERVASI IN-SITU PT PEMBANGKIT JAWA BALI UNIT BISNIS JASA O \& M PLTU REMBANG
}

\author{
Nita Citrasari*1), Edo Dwi Praptono ${ }^{2)}$, Uslah Hidayati ${ }^{3)}$, Habil Maqdum Faruqi ${ }^{4)}$, \\ Trisnadi Widyaleksono Catur putranto ${ }^{5)}$, Dwi Ratri Mitha Isnadina ${ }^{6}$, Febri Eko \\ Wahyudianto ${ }^{7}$
}

1)24)5567) Program Studi Ilmu dan Teknologi Lingkungan, Departemen Biologi, Fakultas Sains dan Teknologi, Universitas Airlangga. Kampus C Unair Jl Mulyorejo 60115 Surabaya, Jawa Timur

${ }^{3)}$ PT Pembangkit Jawa Bali Unit Bisnis Jasa O \& M PLTU Rembang, Jl Raya Semarang Surabaya Km 130, Desa Leran, Kecamatan Sluke, Kabupaten Rembang, Jawa Tengah e-mail: *1 tata its@yahoo.com

\begin{abstract}
ABSTRAK
Tujuan dari penelitian ini adalah untuk membuat baseline keanekaragaman kupu-kupu di kawasan konservasi insitu PT Pembangkit Jawa Bali Unit Bisnis Jasa O \& M PLTU Rembang. Data tersebut digunakan dalam penyusunan dokumen PROPER menuju peringkat hijau atau beyond compliance, sesuai dengan Lampiran V Peraturan Menteri Lingkungan Hidup Nomor 3 Tahun 2014. Sampling dilakukan dengan dua kombinasi metode, yaitu penangkapan dan perangkap menggunakan umpan buang sepanjang transek. Terdapat lima titik sampling dengan jarak tiap perangkap $\pm 100 \mathrm{~m}$ (Titik I S $06^{\circ} 38.191^{\prime}$ dan E $111^{\circ}$ 28.663'; Titik 2 pada S $06^{\circ} 38.179^{\prime}$ dan E $111^{\circ} 28.696^{\prime}$; Titik 3 pada S $06^{\circ} 38.165^{\prime}$ 'dan E $111^{\circ}$ 28. 728'; Titik 4 pada S $06^{\circ} 38.083^{\prime}$ dan E $111^{\circ} 28.655^{\prime}$; serta Titik 5 yang terletak pada koordinat $\mathrm{S} 06^{\circ} 37.966^{\prime}$ dan E $111^{\circ} 28.616^{\prime}$ ). Kupu-kupu yang diperoleh terdiri atas empat famili dan lima spesies, yaitu Pteridae (1 spesies), Purple emperos (1 spesies), Lycaenidae (1 spesies) dan Nymphalidae (2 spesies). Spesies tersebut secara berurutan, meliputi Eurema hecabe, Hypolimnas bolina, Zizina otis, Junonia orithya madagascarensis, dan Melanitis leda.
\end{abstract}

Kata kunci: baseline, keanekaragaman, kupu-kupu, PROPER, PT Pembangkit Jawa Bali Unit Bisnis Jasa O \& M PLTU Rembang

\section{PENDAHULUAN}

PT Pembangkit Jawa Bali Unit Bisnis Jasa O \& M PLTU Rembang mempunyai komitmen yang tinggi terhadap pengelolaan lingkungan hidup, yang diwujudkan dengan keikutsertaannya dalam PROPER. Peringkat biru telah diperoleh di tahun 2016, target berikutnya mencapai peringkat hijau atau beyond compliance. Dalam menuju peringkat hijau tersebut, perusahaan telah menetapkan kawasan konservasi in-situ di dalam unit operasional. Penetapan kawasan konservasi in-situ bertujuan untuk mempertahankan dan meningkatkan kualitas keanekaragaman hayati sesuai dengan aspek penilaian kriteria Keanekaragaman Hayati dalam PROPER peringkat hijau sesuai dengan Lampiran $\mathrm{V}$ 
Peraturan Menteri Lingkungan Hidup Nomor 3 Tahun 2014 (PRI, 2014).

Pada umumnya konservasi keanekaragaman hayati dalam rangka PROPER dilakukan terhadap flora fauna asli setempat dan flora fauna langka di dunia. Jarang ditemukan upaya konservasi terhadap insekta seperti kupu-kupu. Padahal Indonesia memiliki keragaman kupu-kupu yang berlimpah, yaitu sekitar 1.600 jenis dari 17.500 jenis kupu-kupu di dunia. Kupu-kupu tersebut tersebut tersebar di seluruh Indonesia, bahkan di Makasar terdapat Taman Nasional Bantimurung yang dikenal sebagai The Kingdom of Butterfly. Kekayaan jumlah jenis ini hanya tertandingi oleh negara-negara tropis di Amerika Selatan, seperti Peru dan Brasil yang mempunyai sekitar 3.000 jenis. Indonesia juga memiliki tingkat endemisitas kupu-kupu yang tinggi, dari total jenis kupu-kupu yang ada, lebih dari 35\% endemis Indonesia (Peggie, 2008).

Oleh karena itu, PT Pembangkit Jawa Bali Unit Bisnis Jasa O \& M PLTU tertarik untuk mengkonservasi kupu-kupu endemik Indonesia. Penelitian ini merupakan langkah pertama yang dilakukan, yaitu mengidentifikasi jenis kupu-kupu yang ada di daerah konservasi in situ perusahaan. Tujuannya adalah sebagai baseline keanekaragaman kupu-kupu di kawasan konservasi insitu PT Pembangkit Jawa Bali Unit Bisnis Jasa $\mathrm{O}$ \& $\mathrm{M}$ PLTU Rembang sebelum kemudian dikembangkan upaya konservasi terhadap kupukupu endemik Indonesia yang lain. Manfaatnya, selain dengan tujuan untuk melindungi keberadaan kupukupu endemik Indonesia, nilai keanekaragaman yang tinggi juga diperlukan untuk meningkatkan nilai PROPER menuju beyond compliance.

\section{METODE PENELITIAN}

Sampling kupu-kupu dilakukan di Bulan Juli 2017 dengan dua kombinasi metode, yaitu penangkapan dan perangkap menggunakan umpan buang sepanjang transek. Metode sampling menggunakan perangkap berumpan buah mengikuti metode (Samways et al., 2012). Sampling dengan perangkap berumpan buah digunakan untuk menangkap kupukupu pemakan buah (frugivora), yaitu sebagian dari anggota-anggota famili Nymphalidae (subfamili Charaxinae, Nymphalinae, Morphinae, dan Satyrinae) (Hughes et al., 1998). Perangkap yang digunakan berbentuk silinder yang memiliki diameter $30 \mathrm{~cm}$ dan tinggi $1 \mathrm{~m}$ menggunakan umpan pisang atau nenas yang sangat masak (Devries, 1998; Samways et al., 2010). Sedangkan untuk metode penangkapan langsung, digunakan jaring serangga diameter $40 \mathrm{~cm}$ dan mata jaring $1 \mathrm{~mm}$.

Di lokasi konservasi dipasang lima perangkap yang diletakkan di sepanjang area dengan jarak tiap perangkap $\pm 100 \mathrm{~m}$. 
Koordinat titik sampling kupu-kupu, meliputi: titik 1 terletak pada koordinat $\mathrm{S} 06^{\circ} 38.191^{\prime}$ dan E $111^{\circ}$ 28.663', Titik 2 pada $S 06^{\circ} 38.179^{\prime}$ dan E $111^{\circ} 28.696$ ', Titik 3 pada S $06^{\circ} 38.165^{\prime}$ dan E $111^{\circ} 28.728^{\prime}$, Titik 4 pada $\mathrm{S} 06^{\circ} 38.083^{\prime}$ dan $\mathrm{E}$ $111^{\circ} 28.655^{\prime}$ serta Titik 5 yang terletak pada koordinat $\mathrm{S} \quad 06^{\circ}$ 37.966' dan E $111^{\circ}$ 28. 616'. Perangkap dipasang dengan umpan pisang mulai pagi hari pada pukul 07.00 WIB dan dibiarkan (diamati) selama dua jam. Penangkapan kupukupu dilakukan antara pukul 07.0010.00 WIB dan jam 14.00-17.00 WIB. Kupu-kupu yang tertangkap dimasukkan ke dalam sebuah wadah dalam keadaan hidup untuk diidentifikasi, selanjutnya diawetkan untuk keperluan identifikasi lebih lanjut di laboratorium menggunakan buku panduan pengenalan bergambar (Corbet \& Pendlebury,1992). Selama menunggu sampling dengan metode perangkap dilakukan metode penangkapan langsung. Setelah berhasil diidentifikasi, selanjutnya dilihat status darimasing-masing spesies berdasarkan Peraturan Pemerintah Republik Indonesia Nomor 7 Tahun 1999 tentang Pengawetan Jenis Tumbuhan dan Satwa (PRI, 1999).

\section{HASIL DAN PEMBAHASAN}

Hasil dari penelitian ini memperlihatkan bahwa kupu-kupu yang berhasil ditangkap di area konservasi PT Pembangkit Jawa Bali Unit Bisnis Jasa O \& M PLTU Rembang terdiri atas empat famili dan lima spesies, yaitu Pteridae (1 spesies), Purple emperos (1 spesies),

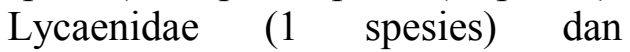
Nymphalidae (2 spesies). Spesies tersebut secara berurutan, meliputi Eurema hecabe, Hypolimnas bolina, Zizina otis, Junonia orithya madagascarensis, dan Melanitis leda. Semua spesies kupu-kupu tersebut tidak termasuk dalam kategori dilindungi berdasarkan Peraturan Pemerintah Republik Indonesia Nomor 7 Tahun 1999 (PRI, 1999). Gambar dan kategori kupu-kupu dapat dilihat di Tabel 1. Jenis tersebut merupakan hasil dari metode penangkapan langsung. Sedangkan dari metode dengan perangkap buah, tidak ada kupukupu yang tertangkap. Pengaruh waktu sampling diduga menjadi faktor utama yang berpengaruh. Sampling dilakukan di Bulan Juni, dimana bulan tersebut belum memasuki musim buah (PRI, 1999). 
Tabel 1. Jenis Kupu-Kupu di Area Konservasi PT Pembangkit Jawa Bali Unit Bisnis Jasa O \& M PLTU Rembang

\begin{tabular}{ccccc}
\hline No. & Spesies & Famili & Gambar & Keterangan \\
\hline 1. & Eurema hecabe & Pieridae & & Tidak \\
& & & & \\
& & & & \\
& & & & \\
& & &
\end{tabular}

2. Junonia orithya Nymphalidae madagascarensis

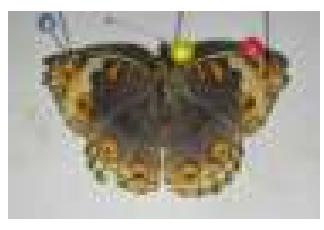

Tidak

Dilindungi

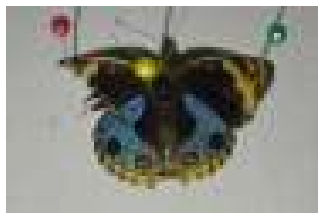

3. Hypolimnas

bolina

Purple

Emperos

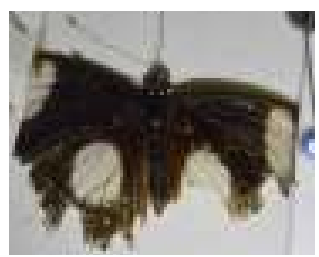

Tidak

Dilindungi

4. Melanitis leda Nymphalidae

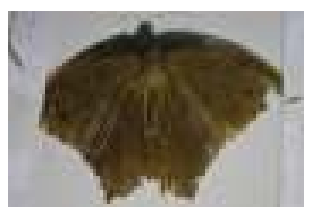

Tidak

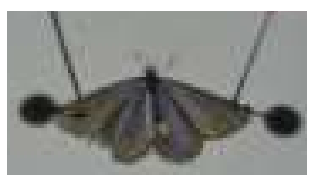

Tidak

5. Zizina Otis Lycaenidae

Kupu-kupu yang ada di Tabel 1 menunjukkan korelasi dengan area sampling, yaitu di area terbuka dengan banyak rerumputan dan perdu, juga di sebagaian area $a$ sh pond dan landfill yang memiliki ciri sebagian wetland dan gurun. Misalnya Zizina Otis, spesies ini 
berhabitat di di hampir semua habitat berumput terbuka termasuk tepian sungai, pinggir jalan, taman dan kebun. Demikian dengan Melanitis leda dan Eurema hecabe. Eurema hecabe bahkan biasa disebut dengan rumput besar kuning atau rumput biasa kuningkarena ditemukan terbang dekat tanah biasanya disekitar rerumputan yang berwarna kuning (Dewenter \& Tscharnte, 2000).

Meskipun spesies tersebut tidak dilindungi, namun kupu-kupu adalah bagian dari ekosistem yang fungsinya mempertahankan keseimbangan ekosistem dan memperkaya keanekaragaman hayati, dilihat dari perannya sebagai penyerbuk yang memungkinkan terjadinya regenerasi tumbuhan. Selain itu juga, kupu-kupu peka terhadap perubahan lingkungan, baik itu dari segi vegetasi maupun dari tingkat pencemaran yang terjadi di lingkungan. Secara ekologis, kupu-kupu dapat dijadikan bioindikator kesehatan suatu lingkungan. Populasi kupu-kupu yang banyak pada suatu tempat mencerminkan lingkungan tersebut masih baik (Shalihah et al., 2012). Untuk menambah keanekaragaman kupu-kupu dan melakukan upaya konservasi, PT Pembangkit Jawa Bali Unit Bisnis Jasa O \& M PLTU Rembang dapat melakukan penangkaran jenis kupukupu yang dilindungi oleh pemerintah. Oleh karena selain fungsi ekologis, kupu-kupu juga memiliki fungsi estetika dan untuk mengetahui indeks keanekaragaman terhadap kupu-kupu tersebut, maka diperlukan monitoring atau pemantau dalam kurun waktu tertentu.

\section{SIMPULAN}

Simpulan dari penelitian ini, yaitu diperoleh empat famili kupukupu dengan lima spesies yang meliputi Pteridae (1 spesies), Purple emperos (1 spesies), Lycaenidae (1 spesies) dan Nymphalidae (2 spesies). Spesiesnya secara berurutan, meliputi Eurema hecabe, Hypolimnas bolina, Zizina otis, Junonia orithya madagascarensis, dan Melanitis leda.

\section{SARAN}

Perlu dilakukan monitoring setiap periode waktu tertentu sehingga dapat dihitung nilai diversitas dan dianalisis metode konservasi yang tepat untuk jenis kupu-kupu yang ada di kawasan konservasi in-situ PT Pembangkit Jawa Bali Unit Bisnis Jasa O \& M PLTU Rembang.

\section{UCAPAN TERIMA KASIH}

Penulis mengucapkan terima kasih kepada Fakultas Sains dan Teknologi dan LPM Universitas Airlangga, serta PT Pembangkit Jawa Bali Unit Bisnis Jasa O \& M PLTU Rembang yang telah mendanai pembuatan penelitian ini.

\section{DAFTAR PUSTAKA}

Corbet AS, Pendlebury HM. 1992. The Butterflies of The Malay 
Peninsula, Fourth edition revised by Lt. Col. J. N. Eliot. Kuala Lumpur: Malayan Nature Society.

Devries P.J., 1988. Stratification of fruit-feeding nymphalid butterflies in a Costa Rican rainforest. Journal of Research on the Lepidoptera 26: 98-108.

Dewenter IS, Tscharntke T. 2000. Butterfly Community in Fragmented Habitats. Ecology Letters, 3.449-456.

Hughes B.G., Daily G.C., and Ehrlich P.R., 1998. Use of fruit bait traps for monitoring of butterflies (Lepidoptera: Nymphalidae), Revista de Biologia Tropical. 46(3): 697704.

Peggie, D., 2008. Кири-Кири, Keunikan Tiada Tara, (Online), (http://biologi.lipi.go.id/bio in donesia/mTemplate.php? $\mathrm{h}=3$

\&id berita $=32$, diakses 28 Oktober 2017.

Pemerintah Republik Indonesia, 1999. Peraturan Pemerintah Republik Indonesia Nomor 7 Tahun 1999 tentang Pengawetan Jenis Tumbuhan dan Satwa.
Pemerintah Republik Indonesia, 2014. Lampiran V Peraturan Menteri Lingkungan Hidup Nomor 3 Tahun 2014.

Samways MJ, Hitchins P, Bourquin O, Henwood J. 2010. Tropical Island Recovery: Cousine Island. Seychelles. Oxford: Wiley Blackwell.

Samways, V.C., Brereton, T., Kirkland, P. \& Warren, M. 2012. Manual for Butterfly Monitoring. Wageningen: De Vlinderstichting/Dutch

Butterfly Conservation, Butterfly Conservation UK \& Butterfly Conservation Europe.

Shalihah A, Pamula G, Cindy R, Rizkawati V, Anwar ZI (2012) Kupu-kupu di kampus Universitas Padjajaran Jatinangor. UNPAD Sumedang.

Yuniastuti, S. dan Suhardjo, 2002, Aplikasi zat pengatur tumbuh paklobutrasol dalan induksi pembungaan mangga', Suhardjo, Sugiyarto, M \& Widajati, E, Monograf mangga, BPTP Jatim, hlm. 54-61. 